\title{
Tomasz Nowak Rozwiązania prawne wprowadzone w latach 2015-2019 w Polsce w celu uszczelnienia systemu podatku od towarów i usług - analiza i ocena wpływu na dochody budżetowe, pewność obrotu gospodarczego i koszty prowadzenia działalności gospodarczej
}

Legal solutions introduced in 2015-2019 in Poland to tighten the VAT system: analysis and assessment of their impact on the state budget revenues, certainty of business transactions and costs of doing business

This paper investigates the effects of legal solutions introduced to the VAT system in Poland in 2015-2019 to prevent VAT fraud, primarily carousel fraud, which caused the so-called tax gap. The article begins with chronological presentation of these solutions. In the second part the author formulates the criteria of certainty of business transactions in relation to VAT and on this basis he analyses the presented solutions. Next, he considers the costs incurred by the VAT payer to meet the obligations or requirements established by the introduced regulations. In the final section the effectiveness of the introduced solutions from the point of view of the state budget revenues from VAT is assessed.

\begin{tabular}{r|l}
\hline DOI & https://doi.org/10.31268/StudiaBAS.2020.30 \\
\hline Słowa kluczowe & $\begin{array}{l}\text { podatnik VAT, podatek naliczony, oszustwa karuzelowe, mechanizm } \\
\text { podzielonej płatności, rejestr podatników }\end{array}$ \\
\hline Keywords & VAT payer, input tax, carousel fraud, split payment, taxpayer register \\
\hline a autorze & $\begin{array}{l}\text { doktor hab. nauk prawnych, Uniwersytet Łódzki, Wydział Prawa } \\
\text { i Administracji, Katedra Prawa Finansowego } \\
\text { @ tnowak@wpia.uni.lodz.pl • ORCID 0000-0001-8372-2348 }\end{array}$ \\
\hline
\end{tabular}

\section{Wstęp}

Wprowadzone w latach 2015-2019 do podatku od towarów i usług (VAT) rozwiązania prawne wpisują się w dążenie ustawodawcy podatkowego do uszczelnienia systemu poboru podatków w Polsce. Wśród działań podejmowanych przez ustawodawcę w tym zakresie w analizowanym przedziale czasowym znaczące miejsce zajmują instrumenty przewidziane dla podatku od towarów i usług. Od lat podatek ten stanowi najistotniejszą pozycję wśród dochodów budżetu państwa. Jednak właśnie w odniesieniu do tego podatku zidentyfikowano zjawiska, których występowanie ma szczególnie jaskrawy charakter i jednocześnie skutkuje pozbawianiem budżetu państwa znaczącej części przysługujących mu wpływów; chodzi przede wszystkim o oszustwa karuzelowe. Wprowadzone w latach 2015-2019 rozwiązania koncentrują się na przeciwdziałaniu wystąpieniu oszustw tego rodzaju, co w założeniu powinno przyczyniać się do zwiększenia wpływów budżetowych z tytułu VAT. Jakkolwiek cel wprowadzenia tych narzędzi jest bezsprzecznie fiskalny, to równocześnie wywierają one znaczący wpływ na sytuację prawną i ekonomiczną 
uczestników obrotu gospodarczego, tj. podatników VAT oraz ich kontrahentów. Wprowadzone rozwiązania wymagają zatem oceny nie tylko z punktu widzenia ich skuteczności w kwestii zwiększenia dochodów budżetowych, lecz także pod kątem ich wpływu na pewność obrotu gospodarczego oraz koszty prowadzenia działalności podatników VAT.

Przedmiotem analizy są wyłącznie rozwiązania ustanowione w VIII kadencji Sejmu RP (tj. kadencji trwającej od 12 listopada 2015 r. do 11 listopada 2019 r.) i wprowadzone w okresie jej trwania.

\section{Zestawienie rozwiązań wprowadzonych w obszarze podatku od towarów i usług w latach 2015-2019}

Wprowadzenie w latach 2015-2019 do podatku od towarów i usług rozwiązań prawnych ukierunkowanych na przeciwdziałanie oszustwom podatkowym nastąpiło w drodze licznych nowelizacji ustawy z dnia 11 marca 2004 r. o podatku od towarów i usług ${ }^{1}$. Moment oraz kolejność wprowadzania tych narzędzi stanowiły, jak się wydaje, funkcję ówczesnej oceny ustawodawcy podatkowego co do skuteczności instrumentów już istniejących oraz zdolności administracji podatkowej do wdrożenia instrumentów nowych. Przykładowo, pierwotnie stopniowo rozszerzano zakres zastosowania mechanizmu odwrotnego obciążenia (reverse charge), aż ostatecznie zastąpiono go obligatoryjnym mechanizmem podzielonej płatności (split payment). Trudno jednak dostrzec w tym zakresie porządek. Dlatego przyjęto chronologiczny sposób przedstawienia wprowadzonych rozwiązań prawnych.

Z dniem 15 lipca 2016 r. - ustawą z dnia 13 maja 2016 r. o zmianie ustawy - Ordynacja podatkowa oraz niektórych innych ustaw² - wyartykułowano klauzulę ogólną nadużycia prawa w VAT. Daje ona organom podatkowym kompetencję do pominięcia skutków podatkowych transakcji, która pomimo spełnienia warunków formalnych ustanowionych w przepisach ustawy miała zasadniczo na celu osiągnięcie korzyści podatkowych, których przyznanie byłoby sprzeczne z celem, któremu służą te przepisy (art. 5 ust. 4 i 5 ustawy o VAT).

Z dniem 1 sierpnia 2016 r. - ustawą z dnia 7 lipca 2016 r. o zmianie ustawy o podatku od towarów i usług oraz niektórych innych ustaw ${ }^{3}$ - wprowadzono rozwiązania przeciwdziałające oszustwom podatkowym z wykorzystaniem wewnątrzwspólnotowego nabycia towarów, którego przedmiotem są paliwa silnikowe (tzw. pakiet paliwowy). Płatnikiem podatku od wewnątrzwspólnotowego nabycia towarów, w przypadku gdy towarem są paliwa silnikowe ${ }^{4}$, ustanowiono zarejestrowanego odbiorcę lub podmiot prowadzący skład podatkowy, dokonujący na rzecz podmiotu, o którym mowa w art. 48 ust. 9 lub art. 59 ust. 8 ustawy z dnia 6 grudnia 2008 r. o podatku akcyzowym, wewnątrzwspólnotowego nabycia w rozumieniu przepisów o podatku

\footnotetext{
Dz.U. nr 54, poz. 535, ze zm.; tekst jednolity: Dz.U. 2020, poz. 106, ze zm.; dalej: ustawa o VAT.

Dz.U. poz. 846. Moment wejścia w życie tej ustawy określono w jej art. 9.

Dz.U. poz. 1052. Moment wejścia w życie tej ustawy określono w jej art. 11.

4 Tzn. towary wymienione w załączniku nr 2 do ustawy z dnia 6 grudnia 2008 r. o podatku akcyzowym (w stanie prawnym obowiązującym od 1 sierpnia 2016 r.) lub w art. 103 ust. 5aa ustawy o VAT (w obecnie obowiązującym stanie prawnym).
} 
akcyzowym (art. 17a ustawy o VAT). Określono tzw. uproszczoną podstawę opodatkowania w art. 30a ust. 2a ustawy o VAT wskazano, iż w celu określenia kwoty zapłaty lub ceny nabycia przyjmuje się ceny paliw silnikowych udostępniane w Biuletynie Informacji Publicznej (BIP) na stronie podmiotowej urzędu obsługującego ministra właściwego do spraw finansów publicznych. Wprowadzono obowiązek odrębnego deklarowania wewnątrzwspólnotowego nabycia paliw silnikowych, przy czym określono krótszy niż w przypadku „zwykłych” deklaracji termin złożenia deklaracji dla czynności tego rodzaju, tj. powinno to nastąpić do 5. dnia miesiąca następującego po miesiącu, w którym powstał obowiązek ich zapłaty (art. 99 ust. 11a ustawy o VAT). Natomiast płatność podatku od wewnątrzwspólnotowego nabycia paliw silnikowych odniesiono do każdej odrębnej transakcji tego rodzaju. Termin zapłaty jest bardzo krótki i w myśl art. 103 ust. 5a pkt 1-3 ustawy o VAT wynosi: 5 dni od dnia, w którym towary te zostały wprowadzone do określonego we właściwym zezwoleniu miejsca odbioru wyrobów akcyzowych (jeżeli towary są nabywane wewnątrzwspólnotowo w rozumieniu przepisów ustawy z dnia 6 grudnia 2008 r. o podatku akcyzowym przez zarejestrowanego odbiorcę z zastosowaniem procedury zawieszenia poboru akcyzy zgodnie z przepisami o podatku akcyzowym), lub 5 dni od dnia wprowadzenia tych towarów z terytorium państwa członkowskiego innego niż terytorium kraju do składu podatkowego, bądź też zapłaty należy dokonać z chwilą przemieszczenia tych towarów na terytorium kraju (jeżeli towary są przemieszczane poza procedurą zawieszenia poboru akcyzy zgodnie z przepisami o podatku akcyzowym).

Z dniem 1 stycznia 2017 r. - ustawą z dnia 1 grudnia 2016 r. o zmianie ustawy o podatku od towarów i usług oraz niektórych innych ustaw ${ }^{5}$ - wprowadzono szereg regulacji rozszerzających zakres funkcjonujących już wcześniej rozwiązań przeciwdziałających oszustwom podatkowym. Katalog dostaw objętych mechanizmem odwrotnego obciążenia został poszerzony o: dostawy srebra, złota, biżuterii, platyny; dostawy procesorów, o ile łączna wartość tych towarów w ramach jednolitej gospodarczo transakcji obejmującej te towary, bez kwoty podatku, przekracza kwotę 20000 zł (jak w przypadku dostaw elektroniki objętych już wcześniej mechanizmem reverse charge); usługi budowlane, o ile usługodawca świadczy te usługi jako podwykonawca.

Jednocześnie okrojono niektóre uprawnienia podatników VAT. Nastąpiło ograniczenie prawa do zwrotu podatku w terminie 25-dniowym. Zgodnie z nowym brzmieniem art. 87 ust. 6 ustawy o VAT z uprawnienia tego może skorzystać podatnik VAT, który ma ten status przez okres 12 miesięcy poprzedzających bezpośrednio okres, w rozliczeniu za który występuje on z wnioskiem o zwrot w terminie 25 dni, i w tym przedziale czasu zostały złożone deklaracje podatkowe za każdy okres rozliczeniowy - i tylko w przypadku, gdy zostały opłacone przekraczające kwotę 15000 zł należności wynikające z faktur stanowiących podstawę odliczenia podatku naliczonego, co zostanie udokumentowane przez występującego o zwrot, oraz pod warunkiem że wykazana w deklaracji kwota podatku naliczonego przeniesionego z poprzednich deklaracji nie przekracza 3000 zł.

W art. 96 ust. 4 ustawy o VAT jako warunek rejestracji podatnika VAT zastrzeżono weryfikację danych zawartych w zgłoszeniu rejestracyjnym VAT, a w ust. 4a tego artykułu określono

5 Dz.U. poz. 2024. Moment wejścia w życie tej ustawy określono w jej art. 21. 
przypadki odmowy zarejestrowania jako podatnika VAT bez konieczności jego powiadomienia, przy czym - uogólniając - przypadki te odnoszą się do sytuacji wskazujących na nierzetelność zgłoszenia. Do art. 96 dodano ust. 4b i 4c, które przewidują odpowiedzialność solidarną pełnomocnika, który złożył zgłoszenie rejestracyjne; pełnomocnik odpowiada solidarnie wraz z zarejestrowanym podatnikiem do kwoty 500000 zł za zaległości podatkowe podatnika powstałe z tytułu czynności wykonanych w ciągu 6 miesięcy od dnia zarejestrowania podatnika jako podatnika VAT czynnego, chyba że powstanie zaległości podatkowych nie wiązało się z uczestnictwem podatnika w nierzetelnym rozliczaniu podatku w celu odniesienia korzyści majątkowej. Ponadto określono dodatkowe przypadki wykreślenia z urzędu z rejestru podatników VAT. W części pokrywają się one z wprowadzonymi tą samą ustawą przypadkami odmowy zarejestrowania jako podatnika VAT (art. 96 ust. 9 ustawy o VAT), w pozostałej zaś części są to: zawieszenie działalności gospodarczej na okres dłuższy niż 6 miesięcy, niewywiązywanie się przez okres 6 miesięcy z obowiązku składania deklaracji na podatek od towarów usług, wystawianie tzw. pustych faktur, a także wiedza lub uzasadnione przypuszczenie organu podatkowego, że dostawcy lub nabywcy biorący udział pośrednio lub bezpośrednio w dostawie tego samego towaru lub usługi uczestniczą w nierzetelnym rozliczaniu podatku w celu odniesienia korzyści majątkowej (art. 96 ust. 9a ustawy o VAT). Z kolei nowe brzmienie art. 97 ust. 15 i 15a ustawy o VAT umożliwia wykreślenie z urzędu podmiotu ujętego w rejestrze podatników VAT UE jako podatnika posiadającego ten status, gdy złoży za 3 kolejne miesiące lub kwartał deklaracje VAT, w których nie wykazał sprzedaży lub nabycia towarów lub usług z kwotami podatku do odliczenia lub przez okres 3 kolejnych miesięcy nie składał informacji podsumowujących pomimo istnienia takiego obowiązku na gruncie art. 100 ustawy o VAT.

Co więcej, wyłączono możliwość składania deklaracji kwartalnych dla podatników innych niż mali podatnicy (art. 99 ust. 2 i 3 ustawy o VAT). Wyłączenie to dotyczy również podatników, u których okres zarejestrowania jako podatników VAT - licząc od miesiąca, w którym dokonano rejestracji - nie przekroczył 12 miesięcy, oraz podatników, którzy w danym kwartale lub w poprzedzających go 4 kwartałach dokonali dostawy towarów, o których mowa w załączniku nr 13 do ustawy (tj. towarów „wrażliwych”, do których odnosi się odpowiedzialność solidarna nabywcy za zaległości podatkowe zbywcy), chyba że łączna wartość tych dostaw bez kwoty podatku nie przekroczyła w żadnym miesiącu z tych okresów kwoty 50000 zł (art. 99 ust. 3a pkt 1 i 2 ustawy o VAT).

Jako obowiązek przewidziano składanie deklaracji w formie elektronicznej (art. 99 ust. 11b ustawy o VAT).

Zawężono przypadki wyłączające odpowiedzialność solidarną nabywcy za zaległości podatkowe zbywcy (tj. odpowiedzialność, o której mowa w art. 105a ustawy o VAT). W tym zakresie dodano przesłankę dokonania przez podatnika nabywającego towary, których nabycie wiąże się z powstaniem przedmiotowej odpowiedzialności, zapłaty za nie w całości na rachunek sprzedawcy w banku mającym siedzibę na terytorium kraju albo na jego rachunek w spółdzielczej kasie oszczędnościowo-kredytowej, której jest on członkiem, wskazany w zgłoszeniu identyfikacyjnym sprzedawcy (art. 105a ust. 3 pkt 3 lit. c ustawy o VAT). Ponadto, oprócz wymienionej w zdaniu poprzednim, dodano - w odniesieniu do podmiotu nabywającego paliwa - przesłankę 
wymagającą od podmiotu dokonującego dostawy tego rodzaju towarów posiadania na dzień poprzedzający dzień dokonania dostawy koncesji wymaganej w wykonywaniu działalności gospodarczej w przypadku dostaw tych towarów (art. 105a ust. 3 pkt 4 ustawy o VAT). Co więcej, odpowiedzialność tę rozciągnięto - przez dodanie poz. 13a, 18a, 18b oraz 22-24 do załącznika nr 13 do ustawy, który zawiera listę towarów objętych tego rodzaju odpowiedzialnością - na folię typu stretch, dyski twarde (dyski HDD) oraz pamięci półprzewodnikowe SSD (dyski SSD), a jednocześnie zawężono ją o niektóre kategorie złota i srebra (w związku z objęciem ich mechanizmem odwrotnego obciążenia) ${ }^{6}$. Zwiększono wymagania stawiane podatnikom wnoszącym kaucję gwarancyjną na zabezpieczenie zapłaty podatku wraz z odsetkami za zwłokę w związku z dokonywaniem dostaw towarów, które są objęte odpowiedzialnością solidarną. Kaucję gwarancyjną mógł złożyć podatnik, który na dzień składania kaucji nie był w trakcie postępowania restrukturyzacyjnego, postępowania upadłościowego albo w trakcie likwidacji (art. 105b ust. 1 pkt 2 ustawy o VAT); podatnik ten upoważnił bank albo spółdzielczą kasę oszczędnościowo-kredytową prowadzącą rachunek wskazany w zgłoszeniu identyfikacyjnym, na który dokonywana jest zapłata z tytułu dostawy towarów wymienionych w załączniku nr 13 do ustawy, do przekazywania organom podatkowym lub organom kontroli skarbowej informacji o wszystkich transakcjach dokonywanych na tym rachunku (art. 105b ust. 1 pkt 4 ustawy o VAT). W odniesieniu zaś do podatników dokonujących obrotu paliwami kaucję gwarancyjną mógł złożyć podmiot, który posiadał koncesje wymagane w wykonywaniu działalności gospodarczej w przypadku dostaw towarów tego rodzaju (art. 105b ust. 1 pkt 3 ustawy o VAT).

Przywrócono sankcje podatkowe związane z zaniżeniem zobowiązania lub zawyżeniem kwoty zwrotu podatku lub podatku naliczonego do przeniesienia na następny okres rozliczeniowy (art. 112b i art. 112c ustawy o VAT).

Z dniem 13 stycznia 2018 r. - ustawą z dnia 24 listopada 2017 r. o zmianie niektórych ustaw w celu przeciwdziałania wykorzystywaniu sektora finansowego do wyłudzeń skarbowych ${ }^{7}$ ustanowiono System Teleinformatyczny Izby Rozliczeniowej (STIR), który służy do: odbioru i przetwarzania danych w celu ustalenia wskaźnika ryzyka; przekazywania danych i informacji o wskaźniku ryzyka do Centralnego Rejestru Danych Podatkowych oraz do systemów teleinformatycznych banków i spółdzielczych kas oszczędnościowo-kredytowych; pośredniczenia w przekazywaniu danych, informacji i żądań pomiędzy Szefem Krajowej Administracji Skarbowej a bankami oraz spółdzielczymi kasami oszczędnościowo-kredytowymi (art. 119zha § 1 ustawy z dnia 29 sierpnia 1997 r. - Ordynacja podatkowa ${ }^{8}$ ). Wykorzystanie STIR może skutkować nawet 72-godzinną blokadą rachunku podmiotu kwalifikowanego, którym jest m.in. podatnik VAT, o ile analiza danych wskaże na możliwość wykorzystywania banków do celów mających związek z wyłudzeniami skarbowymi lub do czynności zmierzających do wyłudzenia skarbowego, a blokada rachunku podmiotu kwalifikowanego jest konieczna, aby temu przeciwdziałać (art. 119zv $\S 1$ o.p.), przy czym blokada ta może ulec wydłużeniu aż do 3 miesięcy (art. 119zw § 1 o.p.).

\footnotetext{
6 B. Bogdański, Zmiany w VAT na 2017 r. - wybrane zagadnienia, „Monitor Podatkowy” 2017, nr 1, s. 17.

7 Dz.U. poz. 2491. Moment wejścia w życie tej ustawy określono w jej art. 27.

8 Dz.U. nr 137, poz. 926, ze zm.; tekst jednolity: Dz.U. 2020, poz. 1325, ze zm.; dalej: o.p.
} 
Z dniem 1 lipca 2018 r. - ustawą z dnia 15 grudnia 2017 r. o zmianie ustawy o podatku od towarów i usług oraz niektórych innych ustaw ${ }^{9}$ - zostało wprowadzone całkowicie nowe rozwiązanie, jakim jest mechanizm podzielonej płatności (split payment). Regulacja prawna tej instytucji została zawarta w dziale XI ustawy o VAT „Dokumentacja”, w którym poświęcono jej rozdział $1 a$ „Mechanizm podzielonej płatności”. Mechanizm podzielonej płatności polega na tym, że „płatność za nabyty towar lub usługę jest dokonywana w taki sposób, że zapłata odpowiadająca wartości sprzedaży netto jest płacona przez nabywcę na rachunek rozliczeniowy dostawcy lub jest rozliczana w inny sposób, natomiast pozostała zapłata odpowiadająca kwocie podatku od towarów i usług jest płacona na specjalny rachunek bankowych dostawcy - rachunek VAT"10. Mechanizm podzielonej płatności miał pierwotnie charakter dobrowolny ${ }^{11}$. Z dniem 1 listopada 2019 r. ustanowiono obowiązkowe jego stosowanie do określonych transakcji².

Z dniem 1 maja 2019 r. - ustawą z dnia 15 marca 2019 r. o zmianie ustawy o podatku od towarów i usług oraz ustawy - Prawo o miarach ${ }^{13}$ - wprowadzono rozwiązanie przewidujące stosowanie tzw. kas fiskalnych online oraz utworzono Centralne Repozytorium Kas. Kasy fiskalne online mają mieć „wbudowaną funkcjonalność umożliwiającą ciągły, zautomatyzowany i bezpośredni przesył danych z kasy rejestrującej do Centralnego Repozytorium Kas"14. Repozytorium jest narzędziem, które służy do odbierania i gromadzenia danych z kas rejestrujących, w tym zwłaszcza danych o sprzedaży, a także do analizy i kontroli danych z rejestru kas rejestrujących (art. 111a ust. 2 pkt 1 i 2 ustawy o VAT). Zgodnie z art. 145a i 146b ustawy o VAT obowiązek prowadzenia kas tego rodzaju dotyczy tylko tych podatników, którzy - uogólniając - prowadzą działalność w sferach bardziej podatnych na oszustwa przy ewidencjonowaniu sprzedaży na rzecz konsumentów. W pozostałych przypadkach kasy spełniające dotychczasowe standardy będą mogły być stosowane nadal, przy czym potwierdzenia o spełnieniu funkcji, kryteriów i warunków technicznych dla kas rejestrujących będą wydawane w przypadku kas z elektronicznym zapisem kopii na okres do 31 grudnia 2022 r., a w przypadku kas z papierowym zapisem kopii - do 31 sierpnia 2019 r. (art. 145a ust. 7 ustawy o VAT), co oznacza, że po tych terminach nie będzie możliwe ich nabycie.

Z dniem 1 września 2019 r. - ustawą z dnia 12 kwietnia 2019 r. o zmianie ustawy o podatku od towarów i usług oraz niektórych innych ustaw ${ }^{15}$ - weszły w życie przepisy tworzące jedną bazę podatników VAT. Z mocy wprowadzonego z tym dniem art. 96b ust. 1 ustawy o VAT wykazem zostali objęci wszyscy podatnicy VAT, a więc nie tylko ci, którzy są zarejestrowani jako podatnicy

9 Dz.U. 2018, poz. 62. Moment wejścia w życie tej ustawy określono w jej art. 11.

10 Uzasadnienie projektu ustawy o zmianie ustawy o podatku od towarów i usług oraz niektórych innych ustaw, druk nr 1864, Sejm VIII kadencji, s. 2.

11 Świadczy o tym użycie przez ustawodawcę w art. 108a ust. 1 ustawy o VAT zwrotu: „Podatnicy [...] mogą [...]”.

12 Uregulowanie to dodano na mocy art. 1 pkt 20-23 ustawy z dnia 9 sierpnia 2019 r. o zmianie ustawy o podatku od towarów i usług oraz niektórych innych ustaw (Dz.U. poz. 1751), której wejście w życie określił jej art. 18.

13 Dz.U. poz. 675. Moment wejścia w życie tej ustawy określono w jej art. 11.

14 Uzasadnienie projektu ustawy o zmianie ustawy o podatku od towarów i usług oraz niektórych innych ustaw, druk nr 2503, Sejm VIII kadencji, s. 1-2.

15 Dz.U. poz. 1018, ze zm. Moment wejścia w życie tej ustawy określono w jej art. 14. 
VAT, w tym ci, których rejestracja jako podatników VAT została przywrócona, lecz także ci, w odniesieniu do których naczelnik urzędu skarbowego nie dokonał rejestracji albo którzy zostali wykreśleni z rejestru jako podatnicy VAT (niezależnie od powodów wykreślenia). W wykazie określa się m.in. status ujętego w nim podmiotu oraz numery rachunków rozliczeniowych STIR (art. 96 b ust. 3 pkt 2a i pkt 13 ustawy o VAT).

Również z dniem 1 września 2019 r. - ustawą z dnia 4 lipca 2019 r. o zmianie ustawy o podatku od towarów i usług oraz niektórych innych ustaw ${ }^{16}$ - listę towarów, których wewnątrzwspólnotowe nabycie zostaje objęte odrębnym deklarowaniem oraz terminem płatności krótszym niż w przypadku ogółu czynności podlegających VAT, rozszerzono o paliwa opałowe.

Z dniem 1 listopada 2019 r. - ustawą z dnia 9 sierpnia 2019 r. o zmianie ustawy o podatku od towarów i usług oraz niektórych innych ustaw ${ }^{17}$ - wprowadzono obowiązek stosowania mechanizmu podzielonej płatności w niektórych sektorach gospodarki. Zgodnie z dodanym do art. 108a ustawy o VAT ustępem 1a stosowanie mechanizmu podzielonej płatności jest obligatoryjne przy dokonywaniu płatności za nabyte towary lub usługi wymienione w załączniku nr 15 do ustawy o VAT, o ile płatności te są udokumentowane fakturą, w której kwota należności ogółem przekracza 15000 zł lub równowartość tej kwoty. Chodzi przede wszystkim o obszary, w których przed tym dniem zastosowanie znajdował mechanizm odwrotnego obciążenia, choć do wykazu dodano nowe towary, które również uznano za szczególnie podatne na oszustwa podatkowe, tj. części i akcesoria do pojazdów silnikowych, węgiel i produkty węglowe, maszyny i urządzenia elektryczne, ich części i akcesoria ${ }^{18}$. Obligatoryjnie działającym mechanizmem podzielonej płatności zastąpiono - stosowany w przeważającej mierze do transakcji dotyczących tych samych towarów i usług - mechanizm reverse charge ${ }^{19}$. Odwrotne obciążenie dla transakcji krajowych zostało w ten sposób zlikwidowane ${ }^{20}$. Odpowiedzialność solidarna została utrzymana tylko dla tych przypadków, gdy nie zostaje zastosowany mechanizm podzielonej płatności²1. Jednocześnie zlikwidowano kaucję gwarancyjną, która wyłączała odpowiedzialność solidarną z tytułu nieodprowadzenia przez dostawcę należnego podatku od transakcji, której przedmiotem była sprzedaż towarów, takich jak wyroby stalowe, paliwa, dyski HDD i SSD, cyfrowe aparaty fotograficzne, folia typu stretch.

Niektóre rozwiązania ustanowione w VIII kadencji Sejmu RP i wprowadzone w obszarze VAT w latach 2015-2019 mają zatem charakter rozwiązań nowych, niektóre zaś polegają na modyfikacji rozwiązań już istniejących. Do tych pierwszych należy zaliczyć przede wszystkim mechanizm podzielonej płatności oraz - związane z ustanowieniem jego obligatoryjności dla wybranych rodzajów transakcji szczególnie podatnych na oszustwa karuzelowe - zniesienie odwrotnego obciążenia dla transakcji krajowych. Nowymi rozwiązaniami są również: publicznie dostępny wykaz podatników VAT oraz obligatoryjna weryfikacja podatnika VAT w procedurze

\footnotetext{
16 Dz.U. poz. 1520. Moment wejścia w życie tej ustawy określono w jej art. 28.

17 Dz.U. poz. 1751. Moment wejścia w życie tej ustawy określono w jej art. 18.

18 W. Słapczyński, Obligatoryjny mechanizm podzielonej płatności, „Przegląd Podatkowy” 2019, nr 11, s. 15.

19 Uzasadnienie projektu ustawy o zmianie ustawy o podatku od towarów i usług oraz niektórych innych ustaw, druk nr 3602, Sejm VIII kadencji, s. 1.

20 Ibidem.

21 W. Słapczyński, op. cit., s. 15.
} 
jego rejestracji w tym charakterze, a także kasy fiskalne online. Za nowe rozwiązanie należy też uznać przywrócenie sankcji VAT. Modyfikacji podlegały natomiast: odwrotne obciążenie w obrocie krajowym (do czasu jego całkowitego zniesienia); rozszerzenie rozliczania każdego poszczególnego wewnątrzwspólnotowego nabycia na paliwa silnikowe, a następnie również na paliwa opałowe; ograniczenie zwrotu nadwyżki podatku naliczonego nad należnym; odpowiedzialność solidarna i związana z nią kaucja gwarancyjna (do czasu jej całkowitego zniesienia). Za modyfikację należy uznać także klauzulę nadużycia prawa - ze względu na to, że była już wcześniej stosowana w praktyce orzeczniczej organów i sądów administracyjnych, zmiana zaś polega jedynie na jej ustawowym wyartykułowaniu².

\section{Wpływ rozwiązań wprowadzonych w latach 2015-2019 w obszarze podatku od towarów i usług na pewność obrotu gospodarczego}

Kryterium pewności obrotu gospodarczego odnoszone do regulacji uszczelniających system VAT należy wiązać z neutralnością tego podatku dla jego podatnika ${ }^{23}$. Jeżeli zatem regulacja prawna zawiera rozwiązania chroniące podatnika VAT przed uwikłaniem w transakcję karuzelową, która - w razie jej zidentyfikowania przez organ podatkowy - często prowadzi do poniesienia przez tego podatnika ekonomicznego ciężaru podatku, to regulację tę należy ocenić pozytywnie z punktu widzenia pewności obrotu gospodarczego. Ocena rozwiązań prawnych wprowadzonych w obszarze VAT z tej perspektywy wymaga przede wszystkim odpowiedzi na pytanie, czy i w jakim stopniu rozwiązania te chronią podatnika VAT przed nabyciem towaru lub usługi, które zostanie uznane przez organ podatkowy za niedające prawa do odliczenia podatku naliczonego przy ich nabyciu lub spowoduje jego odpowiedzialność za powstałe u zbywcy lub świadczeniodawcy zaległości podatkowe ${ }^{24}$. Chodzi zwłaszcza o ochronę podatnika VAT przed poniesieniem negatywnych dla niego konsekwencji prawnych związanych z uczestniczeniem w oszustwie karuzelowym; organy podatkowe najczęściej prowadzą postępowanie wobec podatnika, który w tym układzie znalazł się nieświadomie ${ }^{25}$.

22 Por. np. B. Rogowska-Rajda, T. Tratkiewicz, Stosowanie klauzuli nadużycia prawa w VAT, „Przegląd Podatkowy” 2018, nr 1, s. 13-14; K. Machalica-Drozdek, A. Drozdek, Zasada nadużycia prawa a prawo podatnika do odliczenia podatku VAT na tle unijnego i krajowego orzecznictwa sq̨dów administracyjnych, "Monitor Podatkowy” 2018, nr 3, s. 22-24.

23 Neutralność VAT dla podatnika tego podatku oznacza, że nie powinien on ponosić ekonomicznego ciężaru zapłaty podatku. Zasadę tę realizuje przede wszystkim prawo do odliczenia podatku naliczonego przy nabyciu przez podatnika VAT towarów i usług wykorzystywanych przez niego do wykonywania czynności opodatkowanych tym podatkiem. Por. np. M. Sęk, Podatek od towarów i usług [w:] Prawo podatkowe. Podręcznik dla Podyplomowego Studium Prawa Podatkowego, red. M. Sęk, t. 2, Uniwersytet Łódzki, Łódź 2014, s. 24.

24 Poza zakresem analizy pozostaje ocena wprowadzonych regulacji z punktu widzenia konstytucyjnego wymagania określoności przepisów prawa podatkowego. Ewentualne niedochowanie tych wymogów przez ustawodawcę podatkowego bez wątpienia wpływa negatywnie na bezpieczeństwo obrotu gospodarczego. Celem niniejszego opracowania jest jednak ocena rozwiązań, a nie ich legislacyjnego odzwierciedlenia.

25 Por. np. W. Modzelewski, Podzielona płatność w podatku od towarów i usług: koncepcja, doświadczenia, wnioski, „Doradztwo Podatkowe - Biuletyn Instytutu Studiów Podatkowych” 2019, nr 1, s. 10. 
Wprowadzone w obszarze podatku od towarów i usług w latach 2015-2019 rozwiązania prawne mają niewielkie znaczenie gwarancyjne dla podatników. Tylko w ograniczonym zakresie łączą się z ochroną, która zabezpieczałaby ich przed uwikłaniem w oszustwa podatkowe i przed konsekwencjami, jakie w związku z tym przewiduje prawo podatkowe.

Dokonanie płatności z wykorzystaniem split payment wiąże się z wyłączeniem odpowiedzialności solidarnej podatnika, na rzecz którego dokonano dostawy towarów, za zaległości podatkowe podmiotu dokonującego tej dostawy (art. 105a ustawy o VAT). Ochrona polega więc na niestosowaniu instrumentu przewidzianego dla przypadku, gdy organ podatkowy nie kwestionuje rzetelności faktury, ale stwierdza, że nie doszło do zapłaty wykazanego w niej podatku. Należy przy tym zaznaczyć, że art. 105a ust. 3 pkt 6 ustawy o VAT, który wyłącza solidarną odpowiedzialność podatnika, na rzecz którego dokonano dostawy towarów, z podmiotem dokonującym tej dostawy za zaległości podatkowe tego drugiego podmiotu, wszedł w życie z dniem 1 listopada 2019 r.; pierwotny reżim prawny split payment nie przewidywał tego wyłączenia.

Regulacja mechanizmu podzielonej płatności - ani w przypadku, gdy skorzystanie z niego ma charakter dobrowolny, ani w przypadku, gdy jest to obligatoryjne - nie zawiera natomiast żadnego zastrzeżenia, które odnosiłoby się do prawa do odliczenia podatku naliczonego wykazanego na fakturze, którą organ podatkowy uzna za nierzetelną. Chodzi przede wszystkim o sytuację, w której faktura wprawdzie dotyczy faktycznego nabycia towaru lub usługi, ale nie odzwierciedla rzeczywistego przebiegu tej transakcji (np. ze względu na jej wystawienie przez firmującego). Podatnik, który dokonuje płatności z wykorzystaniem split payment, przez takie działanie nie uzyskuje gwarancji niepodważenia prawa do odliczenia podatku naliczonego ${ }^{26}$. Jedynymi korzyściami dla podatnika są: wyłączenie ustalania dodatkowego zobowiązania podatkowego, tj. sankcji podatkowej związanej z zaniżeniem zobowiązania podatkowego lub z jego niezadeklarowaniem (art. 108c ust. 1 ustawy o VAT), a także wyłączenie podwyższonej stawki odsetek za zwłokę w wysokości 150\%, tj. stawki, o której mowa w art. 56b o.p., w odniesieniu do okresu rozliczeniowego, za który podatnik w złożonej deklaracji podatkowej wykazał kwotę podatku naliczonego, której co najmniej 95\% wynika z otrzymanych przez podatnika faktur, które zostały zapłacone z zastosowaniem mechanizmu podzielonej płatności (art. 108c ust. 2 ustawy o VAT), przy czym świadomość uczestniczenia w oszustwie podatkowym wyłącza i tę korzyść przewidzianą dla faktycznego zastosowania mechanizmu podzielonej płatności (art. 108c ust. 3 ustawy o VAT).

Zwiększeniu bezpieczeństwa obrotu ma służyć stworzenie i funkcjonowanie wykazu podatników VAT, tj. wykazu, o którym mowa w art. 96b ustawy o VAT. Wykaz ten - w kształcie, jaki nadaje mu obecnie obowiązująca regulacja prawna - obejmuje podstawowe informacje o podatnikach VAT oraz o podmiotach, które nie uzyskały tego statusu lub go utraciły. Wykaz ten jest

26 Por. A. Bartosiewicz, Objaśnienie nr 21 do art. 105a [w:] A. Bartosiewicz, VAT. Komentarz, wyd. 14, Wolters Kluwer, Warszawa 2020 (publikacja elektroniczna); W. Zajączkowski, Podzielona płatność. Praktyczne aspekty nowych regulacji, „Monitor Podatkowy” 2018, nr 3, s. 17. Por. również: W. Modzelewski, Luka w koncepcji obowiqzzkowej podzielonej płatności, „Doradztwo Podatkowe - Biuletyn Instytutu Studiów Podatkowych" 2019, nr 2, s. 25 - autor traktuje ten brak jako lukę w koncepcji obligatoryjnego mechanizmu podzielonej płatności. 
udostępniany w BIP na stronie Ministerstwa Finansów (art. 96b ust. 2 ustawy o VAT), a zatem dostęp do zawartych w nim informacji nie jest trudno osiągalny. Wykaz ten, co również wynika z art. 96b ust. 2 ustawy o VAT, ma być prezentowany „w sposób umożliwiający sprawdzenie, w tym automatycznie, czy podmiot znajduje się w wykazie na wybrany dzień, przypadający nie wcześniej niż w okresie 5 lat poprzedzających rok, w którym podmiot jest sprawdzany". Ma to umożliwić podatnikowi VAT weryfikację rzetelności kontrahenta ${ }^{27}$.

Skuteczność wykazu, o którym mowa w art. 96b ustawy o VAT, dla bezpieczeństwa obrotu należy rozpatrywać w kontekście przewidzianej w art. 96 ust. 9 i 9a ustawy o VAT kompetencji organu podatkowego do wykreślenia z rejestru podatników VAT podmiotów, u których stwierdzono - wymienione w tych przepisach - okoliczności wskazujące na ich nierzetelność w rozliczeniach VAT. Wykaz ten nie stanowi „suchego” zbioru danych znajdujących się w urzędzie obsługującym organ podatkowy, ale odzwierciedla rezultaty podejmowanych przez organy podatkowe działań wymaganych przez prawo dla weryfikacji rzeczywistego statusu podmiotów ujętych w rejestrze jako podatnicy VAT.

Problemem może być natomiast sposób przedstawienia danych w BIP i związana z tym zdolność do wyszukiwania danych istotnych. Kluczowe znaczenie ma wybór parametrów, za których pomocą dokonuje się sprawdzenia kontrahenta. Wyszukiwanie może być nieskuteczne w przypadku osób prawnych. Nie jest np. możliwe przeprowadzenie weryfikacji z użyciem kryterium imion i nazwisk osób, które reprezentują osobę prawną w obrocie gospodarczym, a w konsekwencji nie ma możliwości zweryfikowania, czy osobami uprawnionymi do reprezentacji sprawdzanej osoby prawnej nie są osoby, które już wcześniej działały w tym charakterze w podmiotach uczestniczących w oszustwach karuzelowych ${ }^{28}$.

W odniesieniu do informacji zawartych w wykazie podatników VAT nie przewidziano natomiast żadnej wyraźnie zastrzeżonej gwarancji, że podatnik nie poniesie negatywnych skutków transakcji z podmiotem ujętym w wykazie jako podatnik VAT, gdyby ostatecznie okazało się, że podmiot ten uczestniczy w łańcuchu dostaw karuzelowych. Zawarcie transakcji z podmiotem ujętym w tym wykazie w dniu zawarcia transakcji jako podatnik VAT nie chroni przed odpowiedzialnością solidarną, o której mowa w art. 105a ustawy o VAT, ani przed podważeniem prawa do odliczenia podatku naliczonego przy nabyciu towarów i usług objętych tą transakcją.

O gwarancyjnym znaczeniu wykazu podatników VAT można mówić tylko w przypadku, gdy potencjalny kontrahent nie został ujęty w wykazie jako podatnik VAT lub w wykazie zawarto informację o niedokonaniu rejestracji danego kontrahenta lub o jego wykreśleniu z wykazu. Informacja taka stanowi dla podatnika VAT wyraźny asumpt do odstąpienia od transakcji; w przeciwnym razie musi liczyć się z poniesieniem odpowiedzialności solidarnej za zaległości tego kontrahenta lub z brakiem możliwości odliczenia podatku naliczonego. Natomiast informacja o statusie kontrahenta jako podatnika VAT stanowi jedynie potwierdzenie okoliczności, iż wobec tego podmiotu organ podatkowy nie stwierdził dotąd żadnych przesłanek negatywnych z punktu widzenia jego statusu jako podatnika VAT. O iluzoryczności tego rozwiązania z perspektywy

27 A. Bartosiewicz, Czarna lista podatników VAT, "Przegląd Podatkowy” 2018, nr 4, s. 9-10.

28 Ibidem, s. 10. 
bezpieczeństwa obrotu świadczy przy tym fakt, że podmioty biorące udział w oszustwie karuzelowym najczęściej są zarejestrowane jako podatnicy VAT. Niewątpliwej łatwości dostępu do danych zawartych w wykazie nie towarzyszą więc rozwiązania, które przewidywałyby gwarancję dla podatników, którzy skorzystali z tych danych. Nie ma zwłaszcza analogicznych rozwiązań do tych, które funkcjonują w przypadku zastosowania się przez podatnika do utrwalonej praktyki interpretacyjnej.

Ustanowienie wykazu podatników VAT może natomiast skłaniać do potraktowania czynności sprawdzenia kontrahenta w tym wykazie jako warunku sine qua non odliczenia podatku naliczonego. Niezweryfikowanie kontrahenta może być potraktowane przez organy podatkowe jako niedochowanie należytej staranności ${ }^{29}$.

\section{Wpływ rozwiązań wprowadzonych w latach 2015-2019 w obszarze podatku od towarów i usług na koszty prowadzenia działalności gospodarczej}

Kryterium wpływu rozwiązań uszczelniających system VAT na koszty prowadzenia działalności obejmuje 3 aspekty. Po pierwsze, chodzi o koszty czynności stanowiących przedmiot nałożonych na podatników obowiązków podatkowych o charakterze instrumentalnym. Po drugie, analizie należy poddać koszty realizacji nowych lub zwiększonych obowiązków o charakterze podstawowym, tj. związanych z obowiązkiem dokonania zapłaty podatku. Po trzecie, uwzględnienia wymagają koszty powstałe w związku z zaostrzeniem warunków realizacji przysługujących podatnikowi VAT uprawnień, w tym w szczególności prawa do odliczenia podatku naliczonego oraz prawa zwrotu nadwyżki podatku naliczonego nad podatkiem należnym.

Skalę kosztów związanych z koniecznością podejmowania czynności stanowiących przedmiot obowiązków instrumentalnych wyznacza - zapewne niemierzalny - wysiłek organizacyjny lub finansowy po stronie podmiotów, na które te obowiązki zostały nałożone. W części dotyczy on ogółu podmiotów (podatników lub płatników), w części zaś - podmiotów dokonujących wybranych transakcji.

Ogółu podatników dotyczy konieczność zorganizowania działalności w sposób umożliwiający złożenie deklaracji w formie elektronicznej (art. 99 ust. 11a ustawy o VAT); obecnie jest to wyłączna forma sporządzania i składania deklaracji VAT. Uwzględnienia wymaga przy tym, że komunikacja elektroniczna została już wcześniej zastrzeżona jako wyłączna forma sporządzenia i przekazania jednolitego pliku kontrolnego (art. 82 § 1b o.p. ${ }^{30}$ ), nie stanowi zatem formy nieznanej podatnikowi VAT.

Koszty prowadzenia działalności podatników ewidencjonujących sprzedaż z zastosowaniem kas rejestrujących zwiększy - jakkolwiek w przeważającej mierze tylko przejściowo - wprowadzenie obowiązku stosowania kas fiskalnych online. Obowiązek ich stosowania nie odnosi się do ogółu podatników, ale dotyczy tylko tych, którzy prowadzą działalność w sferach bardziej

29 Ibidem.

30 Uchylony z dniem 1 października 2020 r. na mocy art. 3 pkt 3 lit. a ustawy z dnia 4 lipca 2019 r. o zmianie ustawy o podatku od towarów i usług oraz niektórych innych ustaw (Dz.U. poz. 1520, ze zm.). 
podatnych na oszustwa przy ewidencjowaniu sprzedaży na rzecz konsumentów; rodzaje tej działalności zostały określone w art. 145b ust. 2 ustawy o VAT i są wśród nich m.in.: sprzedaż paliw silnikowych, sprzedaż węgla, świadczenie usług gastronomicznych, fryzjerskich, prawniczych. Na podmioty prowadzące tego typu działalność nałożono obowiązek zapewnienia połączenia umożliwiającego przesyłanie danych między kasą rejestrującą a Centralnym Repozytorium Kas (art. 111 ust. 3a pkt 12 i ust. 6a ustawy o VAT). Oznacza to konieczność zapewnienia dostępu do sieci Internet w każdym miejscu, w którym jest prowadzona sprzedaż ewidencjonowana na kasie rejestrującej, a także konieczność zakupu nowego urządzenia. Koszt zakupu urządzenia jest częściowo rekompensowany prawem do odliczenia od podatku należnego kwoty wydanej na zakup każdej z kas rejestrujących w wysokości 90\% jej ceny zakupu (bez podatku), nie więcej jednak niż 700 zł; uprawnienie to jest obecnie związane wyłącznie z nabyciem kasy online (art. 111 ust. 4 ustawy o VAT). Ponadto podatnicy ewidencjonujący sprzedaż z zastosowaniem kas online nie są zobligowani do wydrukowania kopii dokumentów fiskalnych (art. 111 ust. 3a pkt 8 ustawy o VAT) ani nie mają obowiązku zgłoszenia kasy rejestrującej do naczelnika urzędu skarbowego w celu otrzymania numeru ewidencyjnego (uchylono art. 111 ust. 3a pkt 10 ustawy VAT, który przewidywał ten obowiązek).

Podatników innych niż mali podatnicy, którzy przed dniem 1 stycznia 2017 r. korzystali z możliwości deklarowania podatku za okresy kwartalne, obciąża po tym dniu konieczność wywiązania się z obowiązku zadeklarowania podatku w sposób bardziej częstotliwy, tj. wymagający podjęcia czynności w każdym miesiącu (art. 99 ust. 3 ustawy o VAT w brzmieniu obowiązującym od 1 stycznia 2017 r.).

U podatników dokonujących wewnątrzwspólnotowego nabycia paliw silnikowych lub opałowych zaistniała konieczność odrębnego identyfikowania tych transakcji w celu wywiązania się z obowiązku ich odrębnego zadeklarowania i dokonania zapłaty albo w 5-dniowym terminie liczonym od dnia wprowadzenia towarów do miejsca ich odbioru lub od dnia ich wprowadzenia z terytorium państwa członkowskiego innego niż terytorium kraju do składu podatkowego, albo z chwilą przemieszczenia towaru tego rodzaju na terytorium kraju (art. 103 ust. 5a ustawy o VAT).

Zarejestrowanego odbiorcę oraz podmiot prowadzący skład podatkowy - w przypadku gdy dokonuje na rzecz podmiotu, o którym mowa w art. 48 ust. 9 lub art. 59 ust. 8 ustawy z dnia 6 grudnia 2008 r. o podatku akcyzowym, wewnątrzwspólnotowego nabycia w rozumieniu przepisów o podatku akcyzowym - ustanowiono płatnikiem podatku od wewnątrzwspólnotowego nabycia towarów, jeżeli towarem są paliwa silnikowe (art. 17a ustawy o VAT). Wymaga to podjęcia wysiłku organizacyjnego lub finansowego związanego z obliczeniem tego podatku, jego poborem oraz wpłatą do organu podatkowego (art. 8 o.p.).

Koszty prowadzenia działalności w postaci obowiązku zapłaty podatku dotyczą podatników dokonujących wewnątrzwspólnotowego nabycia paliw silnikowych oraz opałowych. Wprowadzenie tzw. pakietu paliwowego jest związane z obowiązkiem odrębnego deklarowania i odrębnej zapłaty tylko dla czynności wewnątrzwspólnotowego nabycia paliw silnikowych lub opałowych. Podatnik dokonujący tej czynności dokonuje zapłaty w terminie krótszym niż w przypadku innych czynności podlegających opodatkowaniu VAT; jest to termin 5-dniowy liczony od dnia dokonania czynności. Zobowiązanie do zapłaty powstaje w odniesieniu do każdego 
wewnątrzwspólnotowego nabycia, tj. każdej zidentyfikowanej odrębnie czynności tego rodzaju, i nie jest kompensowane - przynajmniej do momentu złożenia deklaracji miesięcznej, w której to nabycie zostaje uwzględnione - uprawnieniem do odliczenia podatku naliczonego. W tym okresie zatem zapłata podatku z tytułu wewnątrzwspólnotowego nabycia paliw silnikowych lub opałowych stanowi realne obciążenie ekonomiczne podatnika VAT.

Negatywnie na koszty prowadzenia działalności gospodarczej wpływa również mechanizm podzielonej płatności. Odbiorca płatności dokonanej z wykorzystaniem tego mechanizmu w części przekazanej na specjalny rachunek bankowy VAT - zostaje ograniczony w swobodzie dysponowania środkami uzyskanymi od kontrahenta ${ }^{31}$. Środki te pozostają pod kontrolą państwa do momentu uregulowania przez ich właściciela zobowiązań wobec wierzyciela podatkowego. W ten sposób zabezpiecza się wpłatę do budżetu państwa należnego VAT w prawidłowej wysokości ${ }^{32}$, czego immanentną konsekwencją pozostaje zawieszenie w tym zakresie możliwości dysponowania środkami pieniężnymi stanowiącymi własność podatnika, co z kolei może prowadzić do zachwiania jego płynności finansowej ${ }^{33}$. W piśmiennictwie wskazuje się nawet na konieczność rozważenia przez każdego podatnika, który będzie otrzymywał płatności z wykorzystaniem mechanizmu podzielonej płatności, finansowania zewnętrznego ${ }^{34}$.

Środki znajdujące się na specjalnym rachunku VAT mogą wprawdzie zostać zwolnione, jednak tylko pod warunkiem złożenia wniosku oraz za zgodą organu podatkowego wyrażoną w formie postanowienia. Organ podatkowy odmawia, w drodze decyzji, zgody, jeśli na podatniku ciążą zaległości z tytułu VAT, podatków dochodowych lub akcyzowego, a nawet w przypadku zaistnienia uzasadnionej obawy, że zobowiązania z tych tytułów nie zostaną wykonane (art. 108b ust. 5 ustawy o VAT). Okres oczekiwania na przywrócenie możliwości rozporządzania środkami znajdującymi się na specjalnym rachunku bankowym może wynieść nawet 60 dni, gdyż w tym terminie następuje rozstrzygnięcie o zgodzie na zwolnienie tych środków (art. 108b ust. 3 ustawy o VAT).

Wprawdzie - poza przypadkami dokonywania płatności za towary lub usługi „wrażliwe” oraz w wysokości przekraczającej 15000 zł - zastosowanie mechanizmu podzielonej płatności jest dobrowolne, jednak taki charakter ma tylko dla świadczeniobiorcy ${ }^{35}$. Odbiorca płatności - a więc właściciel środków pieniężnych otrzymywanych za towary lub usługi, czyli podmiot, którego najbardziej dotyka działanie mechanizmu (skoro, choć przejściowo, nie może rozporządzać środkami pieniężnymi stanowiącymi jego własność) - zostaje pozbawiony wpływu na wybór dokonania płatności w ten sposób ${ }^{36}$.

31 K. Kasprzyk, Mechanizm podzielonej płatności, „Przegląd Podatkowy” 2018, nr 8, s. 10.

32 Ibidem.

33 W. Słapczyński, op. cit., s. 14.

34 Ibidem, s. 19.

35 Z art. 108a ust. 1 ustawy o VAT wynika, że o zastosowaniu mechanizmu podzielonej płatności decydują „podatnicy, którzy otrzymali fakturę z wykazaną kwotą podatku”.

36 Por. jednak: J. Matarewicz, B. Senderowski, Alternatywne metody poboru podatku VAT na przykładzie split payment, „Monitor Podatkowy” 2020, nr 2, s. 18. Autorzy przywołują argumenty wskazujące na możliwość umownego uzgodnienia przez strony transakcji stosowania lub niestosowania mechanizmu podzielonej płatności, o ile dla danej transakcji nie ma to charakteru obligatoryjnego. 
Wobec tego w zakresie, w jakim odbiorca należności - a jednocześnie dokonujący dostawy towarów lub świadczący usługę - zostaje zmuszony do tolerowania płatności dokonanej z wykorzystaniem mechanizmu podzielonej płatności, wywiązanie się z obowiązku poniesienia przymusowego świadczenia na rzecz państwa łączy się de facto z przyspieszoną zapłatą podatku (skoro nie można w tym zakresie korzystać ze środków będących własnością podatnika w inny sposób niż wywiązanie się z ogółu ciążących na nim obowiązków podatkowych), a konieczność wystąpienia do organu podatkowego o zgodę na zwolnienie rachunku przywraca pełną rozporządzalność tymi środkami dopiero po 60 dniach od dnia złożenia wniosku o zgodę. W każdym z tych aspektów jest to dodatkowy koszt realizacji obowiązku podatkowego o charakterze podstawowym. W pierwszym z tych aspektów koszt ten zostaje zrekompensowany możliwością obniżenia kwoty zobowiązania podatkowego, w przypadku gdy zapłata zobowiązania podatkowego z tytułu podatku następuje w całości z rachunku VAT w terminie wcześniejszym niż termin zapłaty podatku (art. 108d ustawy o VAT).

Na koszty działalności gospodarczej negatywny wpływ wywiera również ograniczenie bezpośredniego zwrotu podatku. Restrykcyjne rozwiązania dotyczą nowych podatników VAT, dla których wyłączona została możliwość zwrotu w terminie 25-dniowym.

\section{Wpływ rozwiązań wprowadzonych w latach 2015-2019 w obszarze podatku od towarów i usług na dochody budżetowe}

Zapewne nie ma możliwości ustalenia, w jaki sposób poszczególne rozwiązania oddziałują na wielkość wpływów z tytułu podatku od towarów i usług. O skuteczności tych rozwiązań lub jej braku można wnosić z aktywności projektodawczej ministra finansów. Przykładowo, zniesienie mechanizmu odwrotnego obciążenia było spowodowane jego niską skutecznością, co przyznali projektodawcy tej zmiany. W uzasadnieniu rezygnacji z tego mechanizmu wyraźnie wskazano, że „pomimo wprowadzenia odwróconego obciążenia luka w VAT nie zmniejszyła się, a wręcz w niektórych latach rosła, np. w 2013 r. względem 2012 r. była większa, na rekordowo wysokim poziomie, pomimo wprowadzenia odwróconego obciążenia na złom, stal i odpady właśnie w 2013 r."137. W 2019 r. zdecydowano się na zastąpienie odwrotnego obciążenia obligatoryjnie stosowanym mechanizmem podzielonej płatności.

Skuteczność wprowadzonych w latach 2015-2019 rozwiązań w sferze VAT należy zatem rozpatrywać co najwyżej w odniesieniu do ogółu wpływów budżetowych z tego tytułu. Na podstawie sprawozdań z wykonania ustawy budżetowej za lata 2014-2019, a więc zarówno za okresy poprzedzające ustanowienie rozwiązań nowych lub modyfikujących wcześniej funkcjonujące, jak i za okresy występujące już po ich ustanowieniu, wykonanie budżetu w zakresie VAT przedstawia się w następujący sposób: za 2014 r. jest to kwota 124262243 zł, za 2015 r. - 123120798 zł, za 2016 r. - 126584120 zł, za 2017 r. - 156801211 zł, za 2018 r. - 174947071 zł, za 2019 r. $180891751 \mathrm{zt}^{38}$.

37 Uzasadnienie projektu..., druk nr 3602, s. 3.

38 Sprawozdania z wykonania budżetu państwa za lata 2014-2019 i omówienia sprawozdań za te lata są dostępne w Biuletynie Informacji Publicznej: https://www.gov.pl/web/finanse/sprawozdania-roczne [dostęp: 
Wpływy z tytułu VAT wzrosły zatem istotnie od 2017 r. w relacji do lat 2014-2016, w których utrzymywały się na mniej więcej tym samym poziomie. W relacji 2017 r. do 2016 r. ten wzrost wyniósł ok. 24\%, w relacji 2018 r. do 2017 r. - ok. 12\%, a w relacji 2019 r. do 2018 r. - ok. 3\%. W relacji 2019 r. do 2016 r. ten wzrost wyniósł ok. 43\%, w liczbach bezwzględnych zaś ok. 74,4 mld zł. Jak wskazuje Rada Ministrów w kolejnych omówieniach sprawozdań z wykonania ustawy budżetowej za lata 2017-2019, relacja wpływów z VAT do PKB w 2017 r. zwiększyła się o 1,1 pkt proc. w porównaniu z tą samą relacją za rok poprzedni, w 2018 r. wzrost ten ukształtował się na poziomie 0,4 pkt proc., a w 2019 r. nastąpił spadek o 0,3 pkt proc. Natomiast relacja wpływów z VAT do spożycia prywatnego, które - jak wskazano w omówieniu sprawozdania z wykonania ustawy budżetowej za rok budżetowy 2017 - jest „lepszym niż PKB indykatorem bazy podatkowej", w 2017 r. zwiększyła się o 1,9 pkt proc. w stosunku do relacji odnotowanej w roku poprzednim. Relacji tej nie podano już w omówieniach sprawozdań za kolejne lata budżetowe, z czego można wnosić, że nie ukształtowała się tak korzystnie jak w przypadku 2017 r. O pozytywnym oddziaływaniu rozwiązań prawnych wprowadzonych do VAT w latach 2015-2019 można zatem mówić w odniesieniu do tych uregulowań, które zostały ustanowione przed 2017 r. oraz na jego początku.

Jednocześnie jednak w omówieniach sprawozdań z wykonania ustawy budżetowej za kolejne lata budżetowe wskazuje się na wciąż wysoki poziom luki podatkowej. W 2017 r. szacowano ją na 25 mld zł, czyli 14\% potencjalnych wpływów, co miałoby oznaczać jej zmniejszenie o 6 mld zł w porównaniu z okresem poprzednim. W 2018 r. luka ta miała ulec dalszemu zmniejszeniu z poziomu 15,4\% do 12,5\% potencjalnych wpływów. Z kolei w 2019 r. wielkość luki podatkowej miała nie ulec istotniejszej zmianie; w tym roku wyniosła $12,03 \%$ w porównaniu z $12,08 \%$ w roku poprzednim. Wydaje się, że zauważalny w latach 2017-2018 efekt działania nowych rozwiązań wygasł w 2019 r.

\section{Podsumowanie}

Zainteresowanie ustawodawcy podatkowego w obszarze VAT koncentrowało się w latach 20152019 na wprowadzeniu rozwiązań, które przeciwdziałają oszustwom podatkowym, zwłaszcza karuzelowym, co miało skutkować zmniejszeniem luki podatkowej. Kontynuowano przede wszystkim wysiłki ukierunkowane na zabezpieczanie zapłaty podatku przez podmioty działające w branżach szczególnie podatnych na występowanie tych oszustw (zapłata podatku od każdej czynności wewnątrzwspólnotowego nabycia paliw silnikowych czy opałowych, obligatoryjny mechanizm podzielonej płatności, obligatoryjne stosowanie kas fiskalnych online). Starano się wzmocnić proces weryfikacji podmiotów zarejestrowanych jako podatnicy VAT lub ubiegających się o rejestrację z punktu widzenia ich statusu jako podatników VAT, a jednocześnie ustanowiono

\footnotetext{
18 listopada 2020 r.] - w przypadku sprawozdań za lata 2018-2019; https://mf-arch2.mf.gov.pl/ministerstwo-finansow/dzialalnosc/finanse-publiczne/budzet-panstwa/wykonanie-budzetu-panstwa/sprawozdanie-z-wykonania-budzetu-panstwa-roczne [dostęp: 18 listopada 2020 r.] - w przypadku sprawozdań za lata 2014-2017.
} 
instrument umożliwiający potencjalnie każdemu zainteresowanemu sprawdzenie kontrahenta pod kątem jego statusu jako podatnika VAT (publicznie dostępny wykaz podatników).

Rozwiązania, które mają zabezpieczać podatnika VAT przed poniesieniem przewidzianych przez prawo podatkowe skutków związanych z uwikłaniem w oszustwo karuzelowe, nie przewidują istotnych gwarancji dla podatnika VAT, który ma obowiązek lub wolę skorzystania z tych narzędzi. Ani wykorzystanie mechanizmu podzielonej płatności, ani weryfikacja kontrahenta w ewidencji podatników VAT nie wiąże się zwłaszcza z ochroną, która polegałaby na niepodważalności prawa do odliczenia podatku naliczonego przy nabyciu towarów czy usług od tego kontrahenta. Gwarancja zrealizowania podstawowego prawa podatnika VAT nie została zatem zastrzeżona. Jedynie w przypadku dokonania płatności z wykorzystaniem split payment bezpieczeństwo obrotu gospodarczego zostaje zapewnione przez wyłączenie odpowiedzialności solidarnej z odbiorcą płatności, jeśli u tegoż powstała zaległość podatkowa związana z transakcją, której dotyczy dokonana płatność. Ponadto dla dokonującego płatności nie powstają wówczas negatywne konsekwencje zaniżenia zobowiązania podatkowego polegające na ustaleniu dodatkowego zobowiązania podatkowego (sankcji VAT) oraz na podwyższonej do $150 \%$ stawce odsetek za zwłokę. Natomiast dla podmiotów dokonujących weryfikacji kontrahentów z użyciem wykazu podatników VAT nie przewidziano nawet takich zachęt.

Nie wydają się szczególnie dotkliwe koszty związane z wdrożeniem i funkcjonowaniem takich rozwiązań, jak obowiązek składania deklaracji VAT w formie elektronicznej, wprowadzenie kas fiskalnych online, a także - rozumiany jako czynność dokonania płatności - mechanizm podzieIonej płatności. Z bardziej uciążliwymi kosztami muszą liczyć się podatnicy VAT prowadzący działalność w branżach szczególnie podatnych na uwikłanie w oszustwa karuzelowe, tj. dokonujący wewnątrzwspólnotowego nabycia paliw silnikowych oraz opałowych, a także dokonujący transakcji implikujących przyjęcie płatności z wykorzystaniem mechanizmu podzielonej płatności.

Jak wskazują dane gromadzone przez ministra właściwego w sprawach finansów publicznych, wpływy z tytułu VAT istotnie wzrosły w latach 2017-2019 w relacji do wcześniejszych okresów. Okoliczność ta - jakkolwiek udział poszczególnych rozwiązań wprowadzonych w obszarze VAT w latach 2015-2019 wydaje się niemierzalny - potwierdza pośrednio skuteczność tych rozwiązań.

\section{Bibliografia}

Bartosiewicz A., Czarna lista podatników VAT, „Przegląd Podatkowy” 2018, nr 4.

Bartosiewicz A., VAT. Komentarz, wyd. 14, Wolters Kluwer, Warszawa 2020.

Bogdański B., Zmiany w VAT na 2017 r. - wybrane zagadnienia, „Monitor Podatkowy” 2017, nr 1.

Kasprzyk K., Mechanizm podzielonej płatności, „Przegląd Podatkowy” 2018, nr 8.

Machalica-Drozdek K., Drozdek A., Zasada nadużycia prawa a prawo podatnika do odliczenia podatku VAT na tle unijnego i krajowego orzecznictwa sq̨dów administracyjnych, „Monitor Podatkowy” 2018, nr 3.

Matarewicz J., Senderowski B., Alternatywne metody poboru podatku VAT na przykładzie split payment, „Monitor Podatkowy" 2020, nr 2. 
Modzelewski W., Luka w koncepcji obowiqzkowej podzielonej płatności „,Doradztwo Podatkowe - Biuletyn Instytutu Studiów Podatkowych" 2019, nr 2.

Modzelewski W., Podzielona płatność w podatku od towarów i usług: koncepcja, doświadczenia, wnioski „Doradztwo Podatkowe - Biuletyn Instytutu Studiów Podatkowych" 2019, nr 1.

Rogowska-Rajda B., Tratkiewicz T., Stosowanie klauzuli nadużycia prawa w VAT, „Przegląd Podatkowy” 2018, nr 1. Sęk M., Podatek od towarów i ustug [w:] Prawo podatkowe. Podręcznik dla Podyplomowego Studium Prawa Podatkowego, red. M. Sęk, t. 2, Uniwersytet Łódzki, Łódź 2014.

Słapczyński W., Obligatoryjny mechanizm podzielonej płatności, „Przegląd Podatkowy” 2019, nr 11.

Zajączkowski W., Podzielona płatność. Praktyczne aspekty nowych regulacji, „Monitor Podatkowy” 2018, nr 3.

\section{Akty prawne}

Ustawa z dnia 29 sierpnia 1997 r. - Ordynacja podatkowa (Dz.U. nr 137, poz. 926, ze zm.; tekst jednolity: Dz.U. 2020, poz. 1325, ze zm.).

Ustawa z dnia 11 marca 2004 r. o podatku od towarów i usług (Dz.U. nr 54, poz. 535, ze zm.; tekst jednolity: Dz.U. 2020, poz. 106, ze zm.).

Ustawa z dnia 13 maja 2016 r. o zmianie ustawy - Ordynacja podatkowa oraz niektórych innych ustaw (Dz.U. poz. 846).

Ustawa z dnia 7 lipca 2016 r. o zmianie ustawy o podatku od towarów i usług oraz niektórych innych ustaw (Dz.U. poz. 1052).

Ustawa z dnia 1 grudnia 2016 r. o zmianie ustawy o podatku od towarów i usług oraz niektórych innych ustaw (Dz.U. poz. 2024).

Ustawa z dnia 24 listopada 2017 r. o zmianie niektórych ustaw w celu przeciwdziałania wykorzystywaniu sektora finansowego do wyłudzeń skarbowych (Dz.U. poz. 2491).

Ustawa z dnia 15 grudnia 2017 r. o zmianie ustawy o podatku od towarów i usług oraz niektórych innych ustaw (Dz.U. 2018, poz. 62).

Ustawa z dnia 15 marca 2019 r. o zmianie ustawy o podatku od towarów i usług oraz ustawy - Prawo o miarach (Dz.U. poz. 675).

Ustawa z dnia 12 kwietnia 2019 r. o zmianie ustawy o podatku od towarów i usług oraz niektórych innych ustaw (Dz.U. poz. 1018, ze zm.).

Ustawa z dnia 4 lipca 2019 r. o zmianie ustawy o podatku od towarów i usług oraz niektórych innych ustaw (Dz.U. poz. 1520, ze zm.).

Ustawa z dnia 9 sierpnia 2019 r. o zmianie ustawy o podatku od towarów i usług oraz niektórych innych ustaw (Dz.U. poz. 1751). 